\title{
р. голович
}

\section{СОБОРНОСТЬ: ИЗ ИСТОРИИ РУССКОЙ РЕЛИГИОЗНОЙ СОЦИАЛЬНОЙ МЫСЛИ}

ГОЛОВич Радое - Ph.D., доцент философского факультета университета Черногории, Никшич, Черногория (madjo.golovic@gmail.com).

\begin{abstract}
Аннотация. Соборность для определенной части современного российского общества выступает важной идеологической категорией, но ее истоки в русской философии, включая гносеологическое, антропологическое, социально-экономическое, эстетическое и этическое измерения, слабо рефлексируются. Статья предлагает видение идеи соборности в трудах русских религиозных философов XIX - начала XX века. Согласно их идеям материальным аналогом соборности является солидарность, и с ней неразрывно связан древний институт общения. По их мнению, соборность предполагает социальное единство людей и имеет этическую релевантность.
\end{abstract}

Ключевые слова: соборность • солидарность • духовность • свобода • личность • вера • русская идея

DOI: $10.31857 /$ S013216250009389-0

Идея соборности имеет фундаментальное значение в русской культуре. Она conditio sine qua non образа жизни, мышления и познания русского человека. Начало соборности является капитальным достижением и «изобретением» русской культуры и еe diferentia specifica в отношении к западноевропейской культуре [Гулыга, 1992: 82]. Соборность, соборное понимание истины, идея духовной любви, братства, сердечного отношения человека к другому человеку и всему бытийствующему встречаем у многих русских мыслителей. Соборность есть русский национальный архетип.

Анализ творений русской философской мысли не доказывает своеобразный апофеоз «русскости» и прославление превосходства ее культуры, они лишь указывают на ее национальные особенности, которые имеют свое происхождение в православном образе миропонимания и менталитете [Троицкий, 1994]. Свое самое адекватное, на мой взгляд, выражение он получил в идее соборности. Принцип соборности имел ключевое значение в возникновении и духовном формировании русской национальной культуры и философии. И.А. Ильин констатирует: «У нас своя особая вера, свой характер, свой уклад души... У нас иное правосознание и иная государственность. Так было всегда. И так обстоит особенно теперь, после всего перенесенного Россией» [Ильин, 1991: 5-7]. Принцип соборности для И. Ильина является основным животворным и неисчерпаемым источником русского народного жизнетворчества - его веры, истории и культуры. Она есть общий метафизический принцип бытия и главная движущая и творческая сила духовной и социально-политической жизни русского человека. Поэтому русская культура именно благодаря началу соборности отличается от культуры других народов как самобытная соборная культура.

А.С. Хомяков «придал соборности статус философско-мировоззренческой категории и выявил ее многогранное значение» [Булычёв, 2005: 16]. Это не означает, что он открыл неизвестную категорию соборности. Соборность в контексте его философии фигурирует как центральное понятие, интегрирующее все кардинальные аспекты его мировоззрения. Хомяков полагал, что мудрость, живущая в философе, не есть нечто данное ему как частному лицу, и добавлял: «Не верю я любви к народу того, кто чужд семье, и нет любви к человечеству в том, кто чужд народу». Соборность у него - «единство во множестве» 
[Хомяков, 1994: 5]; она «противостоит, как индивидуализму, разрушающему человеческое единство, так и коллективизму, нивелирующему личность» [Моторина, 2009: 84]. Индивидуальное сознание человека не в состоянии понять последнюю и наивысшую истину бытия. Ее можно постичь только общим сознанием, то есть с помощью соборности. Только с помощью целостного духа, соборного познания можно достигнуть истины.

В контексте русской культуры идея соборности выступает как путеводительная идея в рассмотрении позиции и роли человека не только в рамках утверждения его единства с Богом, но и с природой, другими людьми в пространстве и времени (социум) и в конечном итоге в связи с единством человека и человечества с самой вселенной. Славянофилы раскрыли всеобщесоциальный смысл категории соборности, выходящий за границы узких трактовок. Социальным аналогом соборного бытия является община. Соборное общество - это общество общин, в котором гармоническим образом соединены и сохранены свобода личности и автономия общества [Осипов, 2001: 208]. Это единство свободное и непринудительное и противостоит как репрессивному коллективизму, так и либеральному индивидуализму. Кроме упомянутого политического аспекта идея соборности содержит два важных момента: аксиологический и этический. «Историко-социологическая доктрина славянофильства представляет собой своеобразное политическое обоснование возможности и необходимости аксиологического пересоздания мировой цивилизации на религиозно-соборных началах при сохранении в России и возрождении в Западной Европе самодержавно общинных принципов социального бытия» [Холодный, 1994: 76].

По мнению Хомякова, под термином соборности подразумевается не только единство, но и свобода. Католицизм и протестантизм искажают идею соборности, гипостазируя ее конститутивные элементы. Первый - есть единство без свободы, а второй - свобода без единства. Только православие в виде соборности успело сохранить их гармонию, т.е. соединить неприкосновенный принцип личности (свободы) и святое имя единства (общности). С точки зрения К.С. Аксакова, продолжившего линию «социологизации» данного понятия, в соборности «личность свободна, как в хоре».

Развитие идеи соборности в русской философской и социальной мысли. В философском творчестве В. Соловьёва категория соборности трансформирована в идею всеединства. Он отмечает в этой связи: «Я называю истинным или положительным всеединством такое, в котором единое существует не на счет всех или в үщерб им, а в пользу всех. Ложное, отрицательное единство поглощает уходящие в него элементы и само оказывается, таким образом, пустотою; истинное единство сохраняет и усиливает свои элементы, осуществляясь в них, как полнота бытия» [Соловьёв, 1990: 552].

Определение понятия соборность дает Бердяев - «общность в любви» [Бердяев, 1912: 73]. Единство свободы и любви, персонализма и общности по Бердяеву есть «чисто русская идея». Он определяет соборность и как комюнитарность - свободный и духовный вид общности людей, которому чужды абсолютный индивидуализм и абсолютный коллективизм. Вот как он описывает суть понятия соборности: «Соборность противоположна и католической авторитарности, и протестантскому индивидуализму, она означает комюнитарность, не знающую внешнего над собой авторитета, но не знающую и индивидуалистического уединения и замкнутости» [Бердяев, 1971: 166]. Подлинно личностная свобода проистекает по Бердяеву из соборности. Она есть качественное, внутреннее и духовное начало в человеке, суть его личности, несводимое ни на внешнее единство людей (общественность, коллектив), ни на эмпирическую, атомарную индивидуальность человека. Словом, соборность есть истинная метафизическая, духовная природа человека.

С.Н. Трубецкой говорит о соборной природе нашего индивидуального сознания. Личное сознание человека укоренено в некоем общем надындивидуальном, соборном и, в конечном счете, во вселенском сознании, которое проникает в наше сознание, как составная и интегральная часть нашего эмпирического Я, содержащего в себе и элементы универсального, которые его связывают с любым другим индивидуальным сознанием [Трубецкой, 1994]. 
П.А. Флоренский полагал, что принцип «оборотной перспективы», который содержится и выражается в русских иконах, свидетельствует о глубинной соборности, лежащей в основе такого неординарного, непривычного мировосприятия и мировоззрения. Он также формулирует идею соборности, которая характерна для русского философствования. «В философии автор хочет сказать то же самое, что и поэт, показать душу русского народа» [Флоренский, 1990: 31]. В отличие от западной философии, которая зиждется на «уединенном сознании» и экономическом материализме, который «растворяет личное начало в массовом сознании», философия Флоренского являет собой «соборность, хоровое начало, синергизм». «Личность, - пишет он, - тут вся, но во всех, в единстве всех, и ничто вне всех, само по себе» [Флоренский, 2018: 118]. Итак, как и у Хомякова, у него главным атрибутом соборности является единство во множестве. Б.П. Вышеславцев подчеркивает, что «Церковь и соборность зиждутся на более глубоком и интимном общении, нежели общение... contract social», «соборное общение» есть «надприродное, надзаконное» [Вышеславцев, 1992: 33].

Идея соборности, со времен Хомякова став достоянием русской религиозной метафизики, в социальной философии С.Л. Франка получила примечательное оригинальное воплощение. Он считал, что в сознании, как и в общественной жизни человека, наше индивидуальное Я всегда изначально включено... в соборном Мы, из-за чего предшествует каждое его обособленность [Франк, 1992]. Франк утверждает несостоятельность «индивидуального спасения», так как человеческое $Я$ не существует «в себе» и неразрывно связано с нашими ближними, т.е. самим Мы. Соборное единство есть гарант автономии личности и защита от любой попытки насильственного подчинения общему и безликому тотальному единству, с одной стороны, и необходимое условие живого, свободного и подлинно конкретного единства человека с другим человеком и обществом в целом - с другой.

Определение категории соборности дает Н.О. Лосский в «Истории русской философии»: «Соборность - есть сочетание любви и единства многих личностей на основе общей любви к одним и тем же абсолютным ценностям. А.С. Хомяков использовал понятие соборность для учения о церкви, а также для учения о социальном образе жизни» [Лосский, 1991: 518]. Он подчеркивает, что социальное учение о соборности, основываясь на синтезе индивидуальных и универсальных трактовок общества и личности, является показателем высшего уровня интуитивной конкретности философствования, до которого поднялись русские мыслители. Философия соборности по Н.О. Лосскому указывает на единственно точный и адекватный подход в интерпретации социума - духовно онтологический подход к пониманию общества, как органического «единства и свободы многих лиц на основе их общей любви к Богу и всем абсолютным ценностям» [там же].

Таким образом, обобщая суждения русских религиозных философов, можно сказать, что первоначальный смысл понятия «соборность» можно определить, как духовное единство, то есть как общность людей, объединенных верой, которая гарантирует духовную целостность личности, истинность познания, индивидуальную свободу каждого человека в вере и единство всех людей, объединенных христианской любовью.

\section{СПИСОК ЛИТЕРАТУРЫ}

Бердяев Н.А. Алексей Степанович Хомяков М.: Путь, 1912.

Бердяев Н.A. Русская идея. Париж: ҮMСА-Press, 1971.

Булычёв Ю.Ю. К вопросу об отношении начал соборности и об ественности в социальной жизни // Православие и патриотизм. СПб.: Алетейя, 2005.

Вышеславцев Б.П. Этика преображенного эроса. М.: Республика, 1994.

Гулыга А.В. Русский философский ренессанс // Русская идея и современность. М.: Республика, 1992. Ильин И.А. Творческая идея нашего будущего. Об основах духовного характера. Новосибирск:

Русский архив, 1991.

Лосский Н.О. История русской философии. М.: Советский писатель, 1991. 
Моторина Л.Е. Соборность. Нравственность, свобода и любовь, как начало человеческой личности в творчестве А.С. Хомякова // Мат. VII-х Всероссийских чтений «Оптина пустынь и русская культура». Калуга: КГПУ им. К.Э. Циолковского, 2009.

Осипов И.Д. Категория соборности в политической философии славянофильства // Русская философия. Новые исследования и материалы (Проблемы методологии и методики). СПб.: СПбГУ, 2001.

Соловьёв В.С. Первый шаг к положительной эстетике. Соч. в 2 т. 2-е изд. Т. 2. М.: Мысль, 1990.

Троицкий Е.С. О русской идее. Очерк теории возрождения нации. В 2 ч. М.: Русло, 1994.

Трубецкой С.Н. Сочинения. М.: Мысль, 1994.

Флоренский П.А. Сочинения. Т. 2. М.: Правда, 1990.

Флоренский П.А. Из богословского наследия // Богословские труды. Сб. № 17. М.: ПСТГУ, 2018.

Франк С.Л. Духовные основы общества. Введение в социальную философию. М.: Республика, 1992.

Холодный В.И. Идея соборности в славянофильстве. Проблема соборной гносеологии. М.: Коффи, 1994.

Хомяков А.С. О старом и новом. Соч. в 2 т. Т. 1. М.: Медиум, 1994.

Статья поступила: 19.02.20. Финальная версия: 02.03.20. Принята к публикации: 24.03.20.

\section{THE 'SOBORNOST': FROM THE HISTORY OF RUSSIAN RELIGIOUS AND SOCIAL THOUGHT}

\section{GOLOVIC R.}

The University of Montenegro, Montenegro

Radoje GOLOVIC, Ph.D. Assist. Prof., Faculty of Philosophy of the University of Montenegro, Niksic, Montenegro (madjo.golovic@gmail.com).

Abstract. The principle of 'sobornost' expresses the syncretic and organic union of freedom and unity in communication between people, as well as their attitude towards society, nature, God and the world as a whole, and it essentially determines the Russian Orthodox culture. The spirit of 'sobornost' represents the inner harmonious unity and communication of personality based on love. It is the guarantee of the personality's autonomy and the saving corrective to each non-blessed and totalitarian pretension of the community (collective, state, and society) to depersonalize and subjugate it. As a result of such spiritual experience, the Russian culture avoided the extremes of individualism and collectivism that form the core of Western rationalist culture to which the principle of 'sobornost' remained alien. The perspective of 'sobornost' is the key to understanding the Russian religious, artistic, philosophical and sociological tradition. The idea of 'sobornost' is a general metaphysical principle of not only thinking, singing and acting but also conditio sine qua non of the knowledge, morals, and faith of the Russian person. The intention to view the attitude of a person towards God and his/her position in the cosmos in a complete way as the unity in diversity (the ideal of cosmic 'sobornost') and the tendency to unite truth, goodness and beauty, knowledge and faith, thoughts and feelings synthetically and concretely (whole spirit, believing opinion and integral knowledge) represent the leitmotif of all spiritual creativity, beginning with Metropolitan of Kiev Hilarion, then Andrei Rublev, Pushkin, Khomyakov, Kireyevsky, Dostoyevsky, Tyutchev, Solovyov, Berdyaev, S. Trubetskoy, Frank, Sorokin, Ilyin, Panarin, and Semushkin. idea.

Keywords: 'sobornost', solidarity, spirituality, freedom, personality, community, faith, love, Russian

\section{REFERENCES}

Berdyaev N.A. (1912) Aleksey Stepanovich Khomyakov. Moscow: Put'. (In Russ.)

Berdyaev N.A. (1971) Russian Idea. Paris: YMCA-Press. (In Russ.)

Bulychev Yu.Yu. (2005) More on the Relationship between the Principles of Conciliarity and Morality in Social Life. In: Orthodoxy and Patriotism. St. Petersburg: Aleteya. (In Russ.)

Florenskiy P.A. (1990) Essays. Vol. 2. Moscow: Pravda. (In Russ.)

Florenskiy P.A. (2018) From the Theological Heritage. In: Theological Works. Digest No. 17. Moscow: PSTGU. (In Russ.)

Frank S.L. (1992) Spiritual Foundations of Society. Introduction to Social Philosophy. Moscow: Respublika. (In Russ.)

Gulyga A.V. (1992) Russian Philosophical Renaissance. In: Russian Idea and Modernity. Moscow: Respublika. (In Russ.) 
Ilyin I.A. (19991) Creative Idea of our Future. About the Basics of Spiritual Character. Novosibirsk: Russkiy arkhiv. (In Russ.)

Kholodnyy V.I. (1994) The Idea of 'Sobornost' in Slavophilism. The Problem of the Communalist Epistemology. Moscow: Koffi. (In Russ.)

Khomyakov A.S. (1994) About the Old and the New. Oeuvre in 2 vols. Vol. 1. Moscow: Medium. (In Russ.) Losskiy N.O. (1991) History of Russian Philosophy. Moscow: Sovetskiy pisatel'. (In Russ.)

Motorina L.E. (2009) 'Sobornost'. Morality, Freedom and Love as the First Principles of Human Personality in A.S. Khomyakov's Work. In: Proceedings of the $7^{\text {th }}$ all-Russian Readings "Optina Pustyn' and Russian Culture". Kaluga: KGPU im. K.E. Tsiolkovskogo. (In Russ.)

Osipov I.D. (2001) Category of 'Sobornost' in Political Philosophy of Slavophilism. In: Russian Philosophy. New Research and Materials (Issues of Methodology and Methods). St. Pepersburg: SPbGU. (In Russ.)

Solovyov V.S. (1990) The First Step to Positive Aesthetics. Oeuvre in 2 vols. $2^{\text {nd }}$ ed. Vol. 2. Moscow: Mysl'. (In Russ.)

Troitskiy E.S. (1994) About the Russian Idea. An Essay on the Theory of Nation Revival. In 2 parts. Moscow: Ruslo. (In Russ.)

Trubetskoy S.N. (1994) Oeuvre. Moscow: Mysl'. (In Russ.)

Vysheslavtsev B.P. (1994) Ethics of the Transfigured Eros. Moscow: Respublika. (In Russ.)

Received: 19.02.20. Final version: 02.03.20. Accepted: 24.03.20. 